\title{
ENVIRONMENTAL ENRICHMENT FOR NEOTROPICAL PRIMATES IN CAPTIVITY
}

\author{
ENRIQUECIMENTO AMBIENTAL PARA PRIMATAS NEOTROPICAIS EM CATIVEIRO
}

\author{
Vanner Boere ${ }^{1}$
}

- REVIEW -

\section{SUMMARY}

Captivity is an extreme non-natural environment for primates. The success of a breeding colony depends of management and veterinarian procedures which must rely on the knowledge of primates' behavioral needs. Environmental enrichment consists of a series of procedures that improve the quality of life of captive animals by meeting their ethological needs. Enrichment can reduce stress, while increasing animal well being in captivity. Suitable ethical conditions, incidences of behavioral disorders, minimal clinical interventions, low mortality, higher reproduction rates and cost/benefit relationship, reflect directly on the quality of captive breeding colonies. Anthropoids like Neotropical primates possess complex neural structures and relate, in a sophisticated manner, to the environment. This review reports important experiences on enrichment procedures for Neotropical primates and the physiological events which could explain improvement of animal well-being.

Key words: environmental enrichment; non-human primates; Neotropical primates; well-being.

RESUMO

Cativeiro é um ambiente de extremos não naturais para primatas. O sucesso de uma criação de primatas depende do manejo e de procedimentos veterinários que devem considerar as necessidades etológicas dos animais cativos. Enriquecimento ambiental é um conjunto de técnicas que modificam o ambiente, resultando em uma melhora na qualidade de vida dos animais, ao satisfazer as suas necessidades comportamentais. $O$ enriquecimento pode diminuir o estresse e melhorar o bem-estar. Primatas neotropicais se caracterizam por complexas estruturas neurais e se relacionam de maneira sofisticada com o ambiente. $O$ enriquecimento ambiental pode aumentar a qualidade de uma criação ao adequar o manejo a padrões éticos aceitáveis, estimular o repertório normal do comportamento, diminuir a casuística clínica, diminuir a mortalidade, incrementar a taxa reprodutiva e maximizar a relação custo/benefício em uma criação. Esta revisão relata experiências relevantes nos procedimentos de enriquecimento para primatas neotropicais, além de comentar as bases fisiológicas em que essas intervenções melhoram o bem-estar dos animais cativos.

Palavras-chave: enriquecimento ambiental, primatas não humanos, primatas neotropicais; bemestar.

\section{INTRODUCTION}

Breeding primates in captivity serves to research, educational, conservation and recreation purposes. In captivity, the success of a breeding colony depends on the management and veterinarian procedures which must rely on the knowledge of primates' behavioral needs. Environmental enrichment consists of a series of procedures that modify the physical or social environment, improving the quality of life of captive animals by meeting their ethological needs. Environmental enrichment, well-being and stress are associated concepts regarding techniques, physiology and behavior aspects. Enrichment can reduce stress, while increasing animal well-being and health in captivity. Ethological needs of anthropoids like Neotropical primates (Infraorder Platyrrhini), although similar to those of other animals, have great cognitive and emotional components. Maintaining enriched home cages is not only justified by technical aspects. Moral and ethical issues are implicitly involved, especially due to the growing concept that human beings are more and

\footnotetext{
${ }^{1}$ Médico Veterinário, Professor Assistente, MSc, Universidade de Brasília. Departamento de Ciências Fisiológicas, Centro de Primatologia, Universidade de Brasília, 70910-900, Distrito Federal. E - mail: vanner@unb.br. Autor para correspondência.
} 
more similar to other species from a functional perspective. The general public absorbs massive information from the media (regarding animal welfare, animal behavior, cruelty, conservation), and in turn demand more ethical and moral guidelines for maintenance of breeding colonies (MENCH \& KREGER, 1996). Various countries have implemented legislation, regulating the use and treatment of animals, increasing demands on captivity maintenance.

\section{DEVELOPMENT}

Optimal conditions in natural environments are not usually found. However, wild animals develop adaptive responses, adjusting more easily to unforeseen disruptive events. Facing daily, and potentially life-threatening challenges, these animals undergo a selective process, in which certain individuals are better suited to cope with present and future events. There are ontogenetic and phylogenetic basis on this issue. In fact, each individual is the outcome in itself of this selective process that occurred in their ancestors. Animals must adapt to harsh and varying environments, search for food, select suitable shelters, interact with conspecifics, reproduce, play, avoid predators and recognize surroundings. Daily routines impose constant need for alternative and diversified strategies, in which events must be learned, selected, and interrelated to arrive at immediate and future decisions. Individuals do not merely respond automatically to stimuli, but interact selectively and are permanently alert to significant novelties affecting their lives. Therefore, compared to other mammals, primates are strongly predisposed to continuously select and respond to novel stimuli in the environment.

Discrepancies in these processes, due to captive environments, have profound effects on physiological, cognitive and emotional states. Captivity is an incomparably more stationary environment, reducing attention and propensity to seek and relate to novelty. Prolonged periods of low stimulation lead to gradual losses of attention and search capabilities of new stimuli. The environment loses significance and the individual remains in a constant state of boredom. "Environmental poverty", defined as inappropriate social and physical surroundings, related to their ideal needs, can trigger a series of extreme non-adaptive responses. These can either be subtle (e. g., lymphopenia), (BOCCIA et al., 1992; LEONARD \& SONG, 1996), or may develop into more serious disorders, such as stereotyped behaviors, cognitive deficits, emotional disturbances (overt aggressiveness or depression), inadequate mating and death (MEYERHOLZAPFEL, 1968; HARLOW et al., 1971; UNO et al., 1989; MASON, 1991a). Dramatic data on the viability of primate populations in captivity have been reported, estimating, for example, that two in every three primates captured in the wild and taken into captivity, die (CASTRO, 1977). Such an example illustrates the high cost of animal life for starting and implementing captive breeding colonies, decreasing biological diversity and implying in economic losses. Good colony management, including enriched environments, may decrease such unacceptable statistics. By implementing few, general and basic measures of captivity maintenance and enrichment, mortality rates have dropped several times in some colonies (ROBERTS, 1989; personal observation).

Ultimately, extreme non-adaptive responses are due to chronic stress, a neuroendocrinal and psychological response of the organism in an attempt to maintain homeostasis when facing prolonged unfavorable situations. Complete neurological development is enhanced by enriched conditions, potentially influencing behavioral complexity. Induced protein synthesis in nerve tissue, increased weight of key structure involved in cognitive processes, and local synaptic strengthening are observed (ROSENZWEIG, 1996). Adaptive physiological and behavioral responses when facing stressful events depend on neural integrity. Animals in enriched environments are more able to solve problems, as in the maintenance routines of manipulations, clinical check-ups, restraining, weighing, social regrouping and home cage relocations.

Immediate responses to environmental shifts are mediated by two main interdependent control systems, the Autonomic Nervous System (ANS) and the hippocampus and HPA axis (Hypothalamic-Pituitary-Adrenal). Under strong stimulation, ANS activates the adrenal medulla, releasing catecholamines into the bloodstream. Epinephrine, the main hormone released by the adrenal medulla, rapidly anticipates the body for "fight or flight" reactions, through mobilization of glucose and functional inhibition of systems not essential for immediate survival, like the reproductive and digestive systems (SAPOLSKY, 1993). Prolonged action of epinephrine can rapidly lead to cardiac and respiratory collapse. The hippocampal formation and amigdala, constitutes an important station for selecting sensory and emotional information inputs. Its structures and nuclei are considered the bottle-neck structures of 
memory and learning processes (MARKOWITSCH, 1996). During stressful episodes, activation of the HPA axis occurs through afferent projections, both of the hippocampus and amigdala, to hypothalamus. The final result is secretion of glucocorticoids (cortisol) by the adrenal cortex, which mobilizes stored energy, activates gluconeogenesis, impairs anabolism, and acts as a negative feedback mechanism of the ANS and hippocampus-HPA activation. Efficiency of this process depends on the integrity and balance between Type I (or MR, mineralocorticoid) and Type II (or GR, glucocorticoid) receptors (SAPOLSKY,1993). Under intense stress, the ability to regulate the hypothalamic-pituitary-adrenal system in adaptive responses is compromised, due to a impairment of feedback control. Glucocorticoids, through neural metabolism change, diminishing spines of dendrites, mainly in the CA3 region of hippocampus, perform a counterbalance role to protect neurons from action of excitatory neurotransmitters (SAPOLSKY,1993). However, certain levels of atrophy in the hippocampus (UNO et al.,1989) or neuronal death in the gyrus dentate (GOULD et al., 1998), may also be identified during extreme stress. Prolonged and relevant experiences, as in extended periods of stress, alter cellular genetic expression (McEWEN, 1996; ROSENZWEIG, 1996). Reduced ability to sustain tetanic stimulation by excitatory neurotransmitters facilitates neural damages (SAPOLSKY, 1993) through increased calcium uptake, activation of second-messengers, and intracellular metabolite depletion. Neural fatigue, accelerated cell degeneration, and cell death (apoptosis) usually follow. The action of glucocorticoids is time-dependent: severe stress, during certain stages of development, increases aging neural degeneration. However, early and slight age-dependent stimulation postpones this condition (McEWEN, 1996). As cortisol acts permissively towards actions of other hormones, various other systems may be affected. Neurochemical evidences indicate that severe stress, adequately represented by impoverished environments, alter anti-oxidative capabilities in neurons. Other neural pathways, employing different neurotransmitters, are also involved, causing serious motor disorders and consumptive behaviors. Dopaminergic pathways of the mesolimbic and nigro-striatum pathways are associated to rewarding (pleasant) events and voluntary movements, respectively. Changes in dopaminergic sensibility are associated to sustained periods of social isolation, a type of severe stress in primates (LEWIS $\boldsymbol{e t} \boldsymbol{a l}$., 1990; IMPERATO $\boldsymbol{e} \boldsymbol{t} \boldsymbol{a l}$., 1991). Stereotyped behaviors may experimentally be induced by administration of high doses of amphetamines, drugs which increase dopamine levels in the synaptic cleft. Endorfinergic pathways have been implicated in stereotyped behaviors. Recurrent behaviors may lead to an increased internal wellbeing by promoting a state of euphoria (POOLE, 1991). Auto-mutilation syndrome results from dysfunctional interactions between noradrenergic and serotoninergic systems, both of which are implicated in the expression and control of aggressiveness (KRAEMER \& CLARKE, 1990). It has been showed that animals with high aggressive and impulsive behavior have lower brain serotonine levels than tame animals (TRUT, 1999). Finally, movement and exploratory restrictions decrease acetylcholine synthesis in cortical areas of the brain related to cognition (MITSUSHIMA et al., 1998). The outcome from this interaction originates motor, motivational, attention, emotional, and cognitive systems activation, and the expression of behaviors. These, in turn, act mainly to modify the environment. In non-responsive or hostile environments, effects influence neural metabolism directly, modifying behavior.

Simple structural modifications, changes in daily routines and proper socialization are sufficient measures to stimulate and improve the psychological state and welfare of the colony (Figure 1). Stimuli may not necessarily be protective or pleasant. Mild stress stimuli, like brief exposures to simulated predators, may induce behaviors similar to those occurring in the wild, and are, therefore, desirable (CHAMOVE \& MOODIE, 1990; VITALE et al., 1991). Some behaviors will only be expressed in captivity. Marmosets in captivity, for example, sleep in nest-boxes, behavior not observed in natural environments. Other aspects of captive colony management must be evaluated, as seen fit, deciding if changes to be introduced will compromise the group's physical and mental health. Nonetheless, environmental enrichment is mainly aimed at introducing changes in the surroundings, eliciting behavioral patterns normally found in the wild. Some experimental protocols, considering their ethical and methodological aspects, require impoverished environments. However, whenever possible, augmenting stimulation opportunities, maintaining optimal sanitary conditions, providing adequate nourishment and social fulfillment must be taken into consideration. Adequate and enriched surroundings improve animal health, reflect on research quality and influence colony maintenance costs (NOVAK \& SUOMI, 1988).

Ideally, an adequate diagnosis of the environment requires an evaluation of both 


\begin{tabular}{|c|c|c|c|}
\hline Taxon & Enrichment & Results & Referencees \\
\hline Callithrix jacchus & Alternated access to an exercise cage & Increased locomotor activity & HEARN et al., 1978 \\
\hline C. jacchus & Artificial "gum tree" & Active exploration of the apparatus & McGREW et al., 1986 \\
\hline C. jacchus & Increase home cage size and complexity & $\begin{array}{l}\text { Positive behaviors where mainly due do } \\
\text { environmental complexity, than in- } \\
\text { creased home cage size. }\end{array}$ & KERL \& ROTHE, 1996 \\
\hline C. jacchus & $\begin{array}{l}\text { Add new support substrates and increase } \\
\text { foraging difficulty }\end{array}$ & $\begin{array}{l}\text { Increasing foraging; for infants, in- } \\
\text { creased foraging, play and social } \\
\text { grooming }\end{array}$ & PELEGRINO et al., 1997 \\
\hline Callithrix & $\begin{array}{l}\text { Trunks and branches, ground covered } \\
\text { with plants, infra-red lamp }\end{array}$ & $\begin{array}{l}\text { Stress decreased and successful mating } \\
\text { occurred; effective protection against } \\
\text { the cold }\end{array}$ & CARROL, 1991 \\
\hline $\begin{array}{l}\text { Callithrix and } \\
\text { Saguinus }\end{array}$ & $\begin{array}{l}\text { Branches and tree trunks, periodically } \\
\text { rearranged in the home cage }\end{array}$ & $\begin{array}{l}\text { Increased exploration and provided } \\
\text { appropriate substrates }\end{array}$ & $\begin{array}{l}\text { SNOWDON \& SAVAGE, } \\
1989\end{array}$ \\
\hline $\begin{array}{l}\text { Saguinus } \\
\text { mystax, S. labiatus }\end{array}$ & $\begin{array}{l}\text { Foraging tray and dispenser with an } \\
\text { increasing access difficulty device }\end{array}$ & $\begin{array}{l}\text { Successful acceptance of foraging tray, } \\
\text { however unsuccessful with the dis- } \\
\text { penser }\end{array}$ & EVANS et al., 1989 \\
\hline S. oedipus & $\begin{array}{l}\text { Increase number of feeding trays, shifts } \\
\text { in food location, food "search" apparatus } \\
\text { and introduction of new items }\end{array}$ & $\begin{array}{l}\text { Increased exploratory activity; lower } \\
\text { aggressive behaviors }\end{array}$ & GLICK-BAUER, 1997 \\
\hline Saimiri sciureus & $\begin{array}{l}\text { Larger and more complex home cage; } \\
\text { feeding device }\end{array}$ & $\begin{array}{l}\text { Increased locomotor in the beginning, } \\
\text { followed by a decrease in movement; } \\
\text { specie-specific patterns of behavior }\end{array}$ & FRAGASZY, 1979 \\
\hline S. sciureus & $\begin{array}{l}\text { Introduction of novel objects; a appara- } \\
\text { tuses with food rewards }\end{array}$ & $\begin{array}{l}\text { Increased manipulation, while de- } \\
\text { creasing stereotyped behaviors }\end{array}$ & BOINSKI et al., 1994 \\
\hline Cebus capucinus & $\begin{array}{l}\text { Different food dispensers, with difficulty } \\
\text { to obtained food items }\end{array}$ & $\begin{array}{l}\text { Foraging, rest and movement closely } \\
\text { resembled naturally occurring behav- } \\
\text { ioral patterns }\end{array}$ & HAYES, 1990 \\
\hline Cebus apella & $\begin{array}{l}\text { Larger enclosure and socialization with } \\
\text { conspecifics }\end{array}$ & $\begin{array}{l}\text { Reduced stereotyped behaviors and } \\
\text { calmer behaviors }\end{array}$ & BAYNE et al., 1991 \\
\hline Alouatta fusca & $\begin{array}{l}\text { Fresh food similar of the natural envi- } \\
\text { ronment food, adequate substrates, so- } \\
\text { cialization with conspecifics and mild } \\
\text { human contact }\end{array}$ & $\begin{array}{l}\text { Restored of specie-specific behavioral } \\
\text { patterns; increasing of weight and } \\
\text { health condition }\end{array}$ & HIRANO et al., 1999 \\
\hline
\end{tabular}

Figure 1 - Relevant examples of environmental enrichment for Neotropical primates in captivity.

physiological and behavioral indicators (MENDOZA, 1991). A simple health parameter consists in periodically evaluating the weight and growth curves of the animals. Clinical history showing frequent occurrences of diseases and skin lacerations indicate to inadequate captive environments. Other auxiliary laboratory parameters are used to evaluate chronic stress, such as cortisol and its metabolite levels in the plasma, urine, feces or saliva (COE \& ROSENBLUM, 1978; SALTZMAN et al., 1994; SMITH \& FRENCH, 1997). In this case, one have keep in mind that physiological cortisol levels in Neotropical primates is too higher than Old World monkeys (BRANDON et al, 1989). Leukocyte evaluation is also useful, where linfopenia was found to be associated, to some extent, to stress and behavioral disorders (LEONARD \& SONG, 1996).

Ethological indicators are measures more easily accessible to detect inadequate individual needs in captivity. Prior to any change to be introduced, one must have good background knowledge of the species in consideration. In the absence of available data for that species, one must consider the closest taxonomic level. Some behaviors are especially disturbed by stress: increased aggressiveness, abnormal behaviors, and disorderly locomotor activities, with lower body contacts and grooming (CHAMOVE et al., 1988; SCHOENFELD, 1989). Frequent scratching and reduced exploratory behaviors are observed in anxiety, a psychological and physiological state of anticipated fear (BAKER \& AURELI, 1997; BARROS et al., 2000).

Animals maintained in impoverished environments seem to have lower expectations towards stimuli in their surrounding, decreasing motor performance, motivation and consumptive behaviors (CARLSTEAD, 1996). This unresponsive scenario constitutes a state of boredom that, under the impact of intense stimuli, may lead to sudden death. Under these same conditions, some individuals develop alternative strategies in the hope of increasing environmental stimulation, such as coprophagy, hyperaggressiveness, hypersexuality, inappropriate sexual behavior (copulating attempts with objects), abnormal postures, low socialization, 
auto-mutilation, stereotyped behaviors and overt expression of some normal behaviors out of context.

Stereotyped behaviors are invariable and repetitive movement patterns, devoid of purpose and function. Although the etiology is not unique, stereotyped behaviors are not observed in the wild. Whenever identified, they act as an indicator of strong aversive components in the environment where the animal lives or lived. Frequent stereotyped behaviors observed in primates include pendulum-like movements of the body, or bodily parts, bizarre postures, self-hugging, walking along the same route during long periods of time, repeated unnecessary movements, biting own body, hyperfagia and polidipsia (MASON, 1991a; personal observation).

Social environment, quantity of available food, nutrient quality and extreme climatic conditions influence levels of play (THOMPSON, 1996). In captivity, greater incidence of play behaviors in young primates are observed, when compared to natural environments (STEVENSON \& POOLE, 1982). Absence of play in captivity can indicate little stimulation, inadequate social surroundings or sickness (POOLE, 1991). Parental care and adequate mating are also considered good parameters of properly adjusted captive behavioral conditions and mental health (ROBERTS, 1989).

\section{ENRICHMENT PROCEDURES}

Although some important studies exist (e. g., BOINSKI $\boldsymbol{e}$ t al., 1994, KERL \& ROTHE, 1996; EVANS et al., 1989), a better understanding of colony management and enrichment, for most neotropical species, is still necessary. The main factors considered in enrichment programs include hygiene, space and complexity, diet, social composition, and personnel involved.

\section{HYGIENE, HEALTH AND FOOD}

Veterinary conducts for animal sanitation are responsible, in part, for the lack of more complex captive environments. During some procedures, like quarantine, isolation is justifiable, while also maintaining strict aseptic control of these enclosures. Ideally, one aims at obtaining a clean, pathogen-free environment, with an enriched surrounding. When implementing such programs, injuries inflicted by objects, their location in enclosures, ingestion, contamination and intoxication must be avoided. In addition to its nutritional significance, food is one of the main factors employed in captive environmental innovations. Within an optimal nutritional perspective, small offers of new food items can sufficiently change daily routines. Periodical changes in food location and the introduction of hidden items induce exploratory behaviors. In larger groups, more feeding apparatuses must be offered to decrease the possibility of persistent exclusions of subordinate individuals. Such measure also increases the probability that a preferential location for food develops.

\section{PHYSICAL ENVIRONMENT}

More than just physical space, environmental complexity or novelty have been considered a basic element for enrichment (WOOLVERTON et al., 1989). Complex enclosure designs may reduce emotional reactions (CHAMOVE, 1989). Physical space must allow all individuals to explore different substrates and to access all parts of the enclosure. Home cage size and complexity must provide spontaneous movements, while inducing ample expression of motor repertoire. Wooden perches in various positions increase available space, also providing segregation and avoidance options for subordinate individuals. Tree trunks, branches, ropes partially mimic the variability of natural-occurring substrates (SNOWDON \& SAVAGE, 1989). For marmosets, softwood for gouging, performed by their specialized incisors, must be made available. Including branches and too many perches in the enclosure has the disadvantage of increasing restraining difficulty from within the home cage, when necessary. Techniques of training conditioning the animals to enter a restraining cage may counterbalance these undesired effects of environmental enrichment. Refuge space, with at least two nest-boxes, can enrich cage environment in most species of primates by allowing individuals under tension to hide or seek protection. Floors covered with wood shaving or leaves provide more natural conditions, positive esthetical effects, and, at the same time, decrease excremental odors. For colonies exposed to public visitation, enriched environments simulating natural conditions not only improve the individuals' quality of life, but also has an significant esthetical and educational effect.

Primates possess enormous curiosity towards objects, more due to novelty than object characteristics in itself. However, studies which introduced toys and plastic balls failed to demonstrate a decrease in abnormal behaviors. These items rapidly lost their novelty element, being unhygienic and easily destroyed (CROCKET $\boldsymbol{e}$ t al., 1989; EVANS et al., 1989). Anthropoids in general 
are more responsive to tasks involving positive reinforcements (e. g., food items) in apparatuses demanding some kind of manual control by the subject, even when food is abundant. However, prior considerations about inducing fear-related behaviors by introducing an apparatus to enrich the environment must be made. This undesired effect depends on the nature of the apparatus, location in the subjects' enclosure, sudden exposure or person who introduces it.

Bone metabolism disorders and low fertility may result from lack of suitable luminosity in diurnal species. In outdoor captive systems, as in natural environments, individuals have been observed spending time relaxing in sunlight. Reports have correlated light as a factor able to modify locomotor activity, promote affiliate and reproductive interactions (BOX \& ROHRHUBER, 1993), or sometimes induce aggressiveness (WOOLVERTON et al., 1989).

\section{SOCIAL ENVIRONMENT}

Presence of another compatible conspecific in the enclosure is considered the greatest enrichment measure for primates (REINHARDT \& REINHARDT, 2000). The first and most crucial social contact occurs during infancy, through mother-infant bonding. Common consensus states that young animals raised in the presence of their mothers, even long after weaning, leads to normal reproduction and behavior patterns during adulthood (MASON, 1991b). In many species, the whole group participates in parental care, important for the development of the young. Social play is important for psychomotor development, social skills acquisition, and emotional balance (BALDWIN \& BALDWIN, 1977; THOMPSON, 1996). Young animals must remain in the company of other animals, for the outcome in social competency may be long lasting, even when early isolation occurs (WOOLVERTON et al., 1989). Partners are a constant source of stimulation and interaction. Group life permits grooming between individuals, a widespread behavior among primates that relieves tension. Socialization induces learning of emotional states in other individuals, increasing one's ability to interpret and socially respond in a more efficient manner. Quartering closely related species is justifiable, when sufficient conspecifics are not available to share home cages. Even with allomothering, individuals seem to develop normally (GUERRA $\boldsymbol{e t}$ al., 1998).

When first implementing social modifications, absence of aggressive encounters does not necessarily imply social acceptance. Gradual introduction, allowing individual to familiarize with each other is therefore recommended. Gradual contacts avoid sudden social changes in established groups, and redirection of aggression to the strange element, including fatal consequences. Frequent relocations of the animals between different groups, result in social instability due to affiliative bond rupture. Overpopulation in enclosures constitutes a serious impoverishment condition. In both cases, metabolic degeneration, like atherosclerosis (KAPLAN et al., 1991), may occur. Psychological confrontations between neighbors must be evaluated, for behavior patterns may be directly affected. "Natural" visual barriers, like a green fence, can relieve tension and mimic natural environments, while adding pleasant esthetic effects. Primates seem capable of recognizing and categorizing humans (MITCHELL et al., 1991). The voice of caretakers may act as positive rewards. Speaking gently near and to the animals induces positive behaviors (SNOWDON \& SAVAGE, 1989).

\section{LEARNING}

Taking advantage of primates' strong propensity to learn, colony management and quality of life may be improved by implementing routines. Training, when followed by carefully intervened contacts and reinforcements, is enriching in itself, for most of the time subjects readily engage in these activities. Studies on cooperative conditioned training tasks have demonstrated decreases in stereotyped behaviors and an overall individual improvement (MARKOWITZ, 1979). Primates can be actively trained to cooperate in management routines, like venopunction, weighing, restraining, clinical exams and home cage cleaning, always using positive reinforcement criteria (REINHARDT, 1997). Conditioning presents the advantage of attenuating autonomic responses by avoiding maximal stimulation during which pain is minimized, perception reduced and defensive behaviors efficiency diminished. In addition to enrichment advantages, routines derived from learned experiences bring subjects closer to their caretakers, increase security aspects for all involved, reduce risk of accidents, lower the incidence of stress and save time. To establish that learning has occurred, positive cooperation criteria are demonstrated when stimulus is presented to the subject. Individuals must always be trained considering probable behavioral patterns expressed in natural environments. By avoiding overcharges to 
physiological systems, physical and psychological lesions are consequently minimized. Fear, impatience or brutality must not demonstrated during the training processes (REINHARDT, 1997).

\section{CONCLUSION}

At least two out of the following categories are necessary to qualify captivity conditions as satisfactory (NOVAK \& SUOMI, 1988): good physical health, complete behavioral repertoire, absence of chronic stress, and problem solving abilities. Alternatively, a desired behavior in captivity is one that is adaptive. That is, one capable of solving certain situations and increasing comfort, while not inducing harm to conspecifics nearby (POOLE, 1991). Personnel and animal security are a priority, independent from the goal of the environment enrichment program implemented. Anticipating responses should be considered prior to introducing novel enrichment elements. For most parts, humans represent potential threats to other primates. Growing evidence indicate, however, that interactions between captive animals and maintenance personnel may lead to improvements in daily routines, constituting an important enrichment measure. Primates also seem to develop sympathies or antipathies towards certain people (personal observation), which should always be considered during maintenance routines. The world for nonhuman primates, may seem threatening, capable of inflicting pain and psychological distress, when physiological and ethological needs are disregarded. Animals understand the relationships surrounding them, possibly through conscious awareness of being an integrated element of the world, hoping to satisfy their needs. To grasp this concept is to take the first step towards comprehending the challenges to be faced when implementing environmental enrichment programs.

\section{REFERENCES}

BAKER, K.C., AURELI, F. Behavioural indicators of anxiety: an empirical test in chimpanzees. Behaviour, Leiden, v.134, p.1031-1050, 1997.

BALDWIN, J.D., BALDWIN, J.I. The role of learning phenomena in the ontogeny of exploration and play. In: CHEVALIER-SKOLNIKOFF, S., POIRIER, F.E. Primate bio-social development: biological, social, and ecological determinants. New York : Garland Publishing, 1977. p.343-406

BARROS, M., BOERE, V., HUSTON, J.P. et al. Measuring fear and anxiety in the marmoset (Callithrix penicillata) with a novel predator confrontation model: effects of diazepam. Behav Brain Res, Amsterdam, v.108, p.205-211, 2000.
BAYNE, K., DEXTER, S., SUOMI, S. Social housing ameliorates behavioral pathology in Cebus apella. Lab Prim Newsl, Madison, v.30, n.2, p.7-11, 1991.

BOCCIA, M.L., LAUDENSLAGER, M.L., CHRISTY, L.B. et al. Immune responses following competitive water tests in two species of macaques. Brain, Behav and Immun, San Diego, v.6, p.201-213, 1992.

BOINSKI, S., NOON, C., STANS, S. et al. The behavioral profile and environmental enrichment of a squirrel monkey colony. Lab Prim Newsl, Madison, v.33, n.4, p.1-5, 1994.

BOX, H., ROHRHUBER, B. Differences in behaviour among adult male, female pairs of cotton-top tamarins (Saguinus oedipus) in different conditions of housing. Anim Techn, Jena, v.44, n.1, p.19 -30, 1993.

BRANDON, D.D., MARKWICK, A.J.,CHROUSOS, $\boldsymbol{e t}$ al. Glucocorticoid resistance in humans and nonhumans primates. Cancer Res, Philadelphia, vol.49, p.2203s -2213s, 1989.

CARLSTEAD, K. Effects of captivity on the bahavior of wild mammals. In: KLEIMAN, D.G, ALLEN, M.E. THOMPSON, K.V., et al. Wild mammals in captivity. Chicago : The University Chicago, 1996. p. 317-333.

CARROL, J.B. The captive breeding of the genus Callithrix at the Jersey Wildlife Preservation Trust. In: RYLANDS, A.B., BERNARDES, A.T. A primatologia no Brasil-3. Belo Horizonte : Fundação Biodiversitas, 1991. p.17-23.

CASTRO, N.R. Lineamientos para la conservacion de primates en el Peru. In: CONFERENCIA INTERAMERICANA SOBRE LA CONSERVACIÓN Y UTILIZACIÓN DE PRIMATES AMERICANOS NO HUMANOS EN LAS INVESTIGACIONES BIOMÉDICAS, 1, 1977, Lima, Peru. Proceedings... Washington : OPS/OMS, 1977. p.228-247. 266p.

CHAMOVE, A.S., MOODIE, E.M. Are alarming events good for captive monkeys? Appl Anim Behav Sci, Amsterdan, v.27, p.169-176, 1990.

CHAMOVE, A.S. Cage design reduces emotionality in mice. Lab Anim, London, v.23, p.215-219, 1989.

CHAMOVE, A.S., HOSEY, J., SCHAETZEL, P. Visitors excite primates in zoos. Zoo Biol, Wismar 2, v.7, p.359-369, 1988.

COE, C.L., ROSENBLUM, L.A. Annual reproductive strategy of the squirrel monkey (Saimiri sciureus). Folia Primatol, Basel, v.29, p.19-42, 1978.

CROCKETT, C., BIELITZKI, J., CAREY, A. et. al. Kong toys as enrichment devices for singly-caged macaques. Lab Prim Newsl, Madison, v.28, n.2, p.5-6, 1989.

EVANS, H.L., TAYLOR, J.D., ERNST, J. et al. Methods to evaluate the wellbeing of laboratory primates: comparisons of macaques and tamarins. Lab Anim Sci, Memphis, v.39, n.4, p.318-323, 1989.

FRAGASZY, D.M. Titi and squirrel monkeys in a novel environment. In: ERWIN, J., MAPLE, T.L., MITCHELL, G. Captivity and behavior. New York : Van NorstrandRheinhold, 1979. p.172-216.

GLICK-BAUER, M. Behavioral enrichment for captive cottontop tamarins (Saguinus oedipus) through novel presentation of diet. Lab Prim Newsl, Madison, v.36, n.1, p.1- 4, 1997. 
GOULD, E., TANAPAT, P., MCEWEN, B.C., $\boldsymbol{e} \boldsymbol{t} \boldsymbol{a}$. Proliferation of granule cells precursors in the dentate gyrus of adult monkeys is diminished by stress. Proc Nat Acad Sci USA, Washington, v.95, p.3168-3171, 1998.

GUERRA, R.F., TAKASE, E., SANTOS, C.V. Cross-fostering between two species of marmosets (Callithrix jacchus and Callithrix penicillata). Rev Bras Biol, São Carlos, v.58, n.4, p.665-669, 1998

HARLOW, H.F., HARLOW, M.K., SCHILTZ, K.A., et al. The effect of early adverse and enriched environments on the learning ability of Rhesus monkeys. In: JARRARD, L.E. Cognitive processes of nonhuman primates. New York : Academic, 1971. p.121-148.

HAYES, S.L. Increasing foraging opportunities for a group of captive capuchin monkeys (Cebus capucinus). Lab Anim Sci, Memphis, v.40, n.5, p.515-519, 1990.

HEARN, J.P., ABBOT, D.H., CHAMBERS, P.C., et al. Use of the common marmoset, Callithrix jacchus, in reproductive research. Prim Med, Basel, v.10, p.40-49, 1978.

HIRANO, Z.M.B., WANKE-MARQUES, S., WANKE, E., et al. Criadouro de espécies da fauna silvestre para fins científicos do Centro de Pesquisas Biológicas de Indaial. In: CONGRESSO BRASILEIRO DE PRIMATOLOGIA, 9, 1999, Santa Teresa, ES. Resumos... Vitporia : CEG, 1999. p.48.

IMPERATO, A., PUGLISI-ALLEGRA, S., CASOLINI, P. et al. Changes in brain dopamine and acetylcholine release during and following stress are independent of the pituitaryadrenocortical axis. Brain Res, Amsterdan, v.538, p.111$117,1991$.

KAPLAN, J.R., ADAMS, M.R., CLARKSON, T.B. et al. Social behavior and gender in biomedical investigations using monkeys: studies in atherogenesis. Lab Anim Sci, Memphis, v.41, p.1-9, 1991.

KERL, J., ROTHE, H. Influence of cage size and cage equipment on physiology and behavior of common marmosets (Calliithrix jacchus). Lab Prim Newsl, Madison, v.35, n.3, p.10-15, 1996

KRAEMER, G.W.,CLARKE, A.S. The behavioral neurobiology of self-injurious behavior in rhesus monkeys. Prog NeuroPsychopharm Biol Psychiat, London, v.14, p.141-168, 1990.

LEONARD, B.E., SONG, C. Stress and immune system in the etiology of anxiety and depression. Pharmacol Biochem Behav, Amsterdam, v.54, n.1, p.299-303, 1996

LEWIS, M.H., GLUCK, J.P., BEAUCHAMP, A.J. Long-term effects of early social isolation in Macaca mulatta: changes in dopamine receptor function following apomorphine challenge. Brain Res, Amsterdan, v.513, p.67-73, 1990.

MARKOWITSCH, H.J. Anatomical basis of memory disorders. In: GAZZANIGA, M.S. The cognitive neurosciences. Cambridge : The MIT, 1996. p. 765-779.

MARKOWITZ, H. Environmental enrichment and behaviora engineering for captive primates. In: ERWIN, J., MAPLE, T.L., MITCHELL, G. Captivity and behavior. New York : Van Norstrand Rheinhold, 1979. p.217-138.
MASON, G.J. Stereotypies: a critical review. Anim Behav, London, v.41, p.1015-1037, 1991a.

MASON, W.A. Effects of social interaction on well-being: development aspects. Lab Anim Sci, Memphis, v.41, n.4, p.323-328, 1991b.

MCEWEN, B.S. Stressfull experience, brain, and emotions: developmental, genetic, and hormonal influences. In GAZZANIGA, M.S. The cognitive neurosciences. Cambridge : The MIT, 1996. p.1117-1135.

MCGREW, W.C., BRENNAN, J.A., RUSSEL, J. An artificial "gum-tree" for marmosets (Callithrix jacchus). Zoo Biol, Wismar 2, v.5, p.45-50, 1986

MENCH, J.A., KREGER, M.D. Ethical and welfare issues associated with keeping wild mammals in captivity. In: KLEIMAN, D.G., ALLEN, M.E., THOMPSON, K.V., et al. Wild mammals in captivity. Chicago : The University Chicago, 1996. p.5-15.

MENDOZA, S.P. Sociophysiology of well-being in nonhuman primates. Lab Anim Sci, Memphis, v.41, n.4, p.344-349, 1991.

MEYER-HOLZAPFEL, M. Abnormal behavior in zoo animals. In: FOX, M.W. Abnormal behavior in animals Philadelphia : Saunders, 1968. p.476-503.

MITCHELL, G., STEINER, S., DOWD, B. et al. Male and female observers evoke different responses from monkeys. Bull Psychon Soc, New Yok, v.29, n.4, p.358-360, 1991.

MITSUSHIMA, D., YAMANOI, C., KIMURA, F. Restriction of environmental space attenuates locomotor activity and hippocampal acetylcholine release in male rats. Brain Res, Amsterdan, v.805, p.207-212, 1998

NOVAK, M.A., SUOMI, S.J. Psychological well-being of primates in captivity. Am Psychol, New York, v.43, n.10, p.765-773, 1988.

PELEGRINO, H.A.S., YAMAMOTO, M.E., SOUSA, M.B.C Efeito do enriquecimento ambiental sobre a frequêencia e distribuição do comportamento em Callithrix jacchus. In: CONGRESSO BRASILEIRO DE PRIMATOLOGIA, 8 , 1997, João Pessoa, Paraíba. Resumos... João Pessoa :UFPB, 1997. p.45.

POOLE, T. Criteria for the provision of captive environments. In: $\mathrm{BOX}, \mathrm{H}$. Primate responses to environmental change. London: Chapman Hall, 1991. p.357-374.

REINHARDT, V. Training nonhuman primates to cooperate during blood collection. Lab Prim Newsl, Madison, v.36, n.4, p.1-5, 1997.

REINHARDT, V., REINHARDT, A. Social enhancement for adult nonhuman primates in research laboratories: a review. Lab Anim, London, vol.29, n.1, p.34-41, 2000.

ROBERTS, J.A. Environmental enrichment, providing psychological well-being for people and primates. Am J Primatol Supp I, Wismar 2, v.1, p.25-30, 1989.

ROSENZWEIG, M.R. Aspects of the search for neural mechanisms of memory. Ann Rev Psychol, New York, v.47, p.1-32, 1996. 
SALTZMAN, W., SCHULTZ-DARKEN, N.J., SCHEFFLER, G., et al. Social and reproductive influences on plasma cortisol in female marmoset monkeys. Phys Behav, Oxford, v.56, n.4, p. 801-810, 1994.

SAPOLSKY, R.M. Neuroendocrinology of the stress-response. In: BECKER, J.B., BREEDLOVE, S.M., CREWS, D. Behavioral endocrinology. Cambridge : The MIT, 1993. p.287-324.

SCHOENFELD, D. Effects of environmental impoverishment on the social behavior of marmosets (Callithrix jacchus). Am J Primatol Supp l, Wismar 2, v.1, p.45-51, 1989.

SMITH, T.E., FRENCH, J.A. Psychosocial stress and urinary cortisol excretion in marmoset monkeys (Callthrix kuhli). Phys Behav, Oxford, v.62, n.2, p.225-232, 1997.

SNOWDON, C.T., SAVAGE, A.S. Psychological well-being of captive primates: general considerations and examples from callithrichids. In: SEGAL, E.F. Housing, care, and psychological well-being of captive and laboratory primates. Park Ridge : Noyes, 1989. p.75-88.
STEVENSON, M.F., POOLE, T.B. Playful interactions in family groups of the common marmoset (Callithrix jacchus jacchus). Anim Behav, London, v.30, p.886-900, 1982.

THOMPSON, K.V. Behavioral development and play. In: KLEIMAN, D.G., ALLEN, M.E., THOMPSON, K.V., et al. Wild mammals in captivity. Chicago : The University Chicago, 1996. p.352-371.

TRUT, L.N. Early canid domestication: the farm-fox experiment. Am Sci, Res Triangle Pk, v.87, p.160-169, 1999.

UNO, H., TARARA, R, ELSE, J.G, et al. Hippocampal damage associated with prolonged and fatal stress in primates. The $\mathbf{J}$ Neurosc, Bethesda, v.9, n.5, p.1705-1711, 1989.

VITALE, A.F., VISALBERGHI, E., DELILLO, C. Responses to a snake model in captive crab-eating macaques (Macaca fascicularis) and captive tufted capuchins (Cebus apella). Int J Prim, New York, v.12, n.3, p.277-286, 1991.

WOOLVERTON, W.L., ATOR, N.A., BEARDSLEY, P.M., et al. Effects of environmental conditions on the psychological well-being of primates: a review of the literature. Life Sci, Oxford, v.44, p.901-917, 1989.

Ciência Rural, v. 31, n. 3, 2001. 